\title{
Voice, Equality and Education: The Role of Higher Education in Defining the Political Participation of Young Europeans
}

\begin{abstract}
Much attention has been paid by academics and policy-makers in recent decades to declining levels of voter turnout and engagement with traditional political and social institutions in established democracies. These trends are particularly marked amongst young people. Drawing on data from the European Social Survey, this article examines the role of higher education (HE) both as a source of unequal participation and as a means of fostering civic and political engagement amongst young Europeans. It uncovers two significant new findings. First, that being in education matters more than an individual's level of educational attainment for levels of civic and political participation, and second, that HE establishments play a key role as social levellers: being in education neutralises differences between young people from high-income and low-income backgrounds with regards to such participation. The article argues that this places added emphasis on the role of educational institutions in nurturing democratic engagement.
\end{abstract}

\section{Keywords:}

young people, inequality, higher education, democratic engagement, civic participation, political participation 


\section{Introduction}

The political participation of young people has become an important theme for academics and policy-makers in recent decades (Cammaerts et al. 2016; European Commission 2007, 2009; Hay 2007; House of Commons Political and Constitutional Reform Committee 2014; Sloam 2016; Stoker 2006; Youth Citizenship Commission 2009). Much attention has been paid to falling levels of voter turnout and a decline in engagement with traditional political and social institutions in established democracies - from political parties, to trade unions, to religious organisations (Fieldhouse et al. 2007; Grasso 2016; Putnam 2000). These trends are particularly marked among young people. Nevertheless, a number of authors have, more positively, pointed to the proliferation of youth participation in a myriad of new forms of engagement since the 2008 financial crisis (Busse et al. 2015; Norris 2011; Pickard and Bessant 2018; Soler-i-Marti, 2015). Indeed, if we take a broad look at political participation - focussing on what young people are actually doing rather than what they are not doing - it is possible to conclude that Millennials and Generation $\mathrm{Z}$ are at least as politically active as previous generations. In this sense, they continue to have a voice.

What is much more open to question, however, is the issue of equality in these new repertoires of participation. What type of young person is most likely to take advantage of this broad spectrum of participation? Voting is generally considered to be a relatively socially equal political act (this is still the case in many European countries, although much less so in the United States). The same, however, cannot be said for alternative forms of engagement, such as signing a petition, joining a boycott, participating in a demonstration, or using social media for political purposes (Marien et al. 2010; Mossberger et al. 2007; Stolle \& Hooghe 2011). Research (Schlozman et al. 2010; Sloam 2013) suggests that the decline in youth participation 
in electoral politics and the shift to alternative forms of engagement has contributed to growing inequalities of participation between young people with high and low socio-economic status. Since young Europeans are more likely to engage in many of these non-electoral forms of participation than older cohorts, our concern is whether this translates into political participation that is less socially equal for young Europeans. In particular, we are interested in the role higher education (HE) plays in addressing these inequalities.

There is a large body of literature (both theoretical and empirical) that has drawn connections between education and democracy (Dewey 1959; Galston 2001; Torney-Purta et al. 2001). The link between civic and political participation and educational attainment is well established in the literature (Nie et al. 1996). In this regard, educational attainment (alongside age) has a more powerful influence upon citizens' levels of political participation than wealth or class (Berinsky and Lenz 2011; Henn and Foard 2014; Verba et al. 1995). However, education is not only important, in a negative sense, for predicting social inequalities of participation; it has also been praised for its capacity to foster civic and political engagement by increasing the political knowledge and understanding (personal efficacy) and democratic skills of young people, and providing the institutional support structures for their transition into adulthood. Politically literate citizens are more likely to participate in democracy, and schools and colleges can play a key role in preparing young people for democratic life (Flanagan \& Levine 2010; Nissen 2019; Torney-Purta et al. 2001).

Many studies have examined falling participation in electoral politics and the emergence of new forms of democratic engagement. However, the real importance of the civic decline thesis may lie in the fact that some groups in society have become less civically (and politically) 
active, and other groups have become more active (Sander \& Putnam 2010). ${ }^{1}$ This trend has major implications for political socialisation. Citizens in our advanced industrial democracies may be more self-reflexive in their politics (Giddens 1991), and increasingly engage with issues that have meaning for their everyday lives (Bang \& Esmark 2009). They may indeed engage politically through social networks across 'hybrid media systems' and 'hybrid public spaces' (Castells 2012; Chadwick 2013). But, as Flanagan (2013) demonstrates, institutions remain central for the socialisation of citizens into practices of democracy, 'scaffolding' their transition from youth to adulthood. If traditional institutions of political socialisation, such as political parties and trade unions, are declining in importance, it follows that the remaining institutions (in this case, universities and colleges) play an even more pivotal role. This is particularly so given the massive expansion of HE in recent decades: the average percentage of 25 to 34 year-olds with university education in the EU (countries that were members before 2014 ) increased from around a quarter in 1995 , to approximately 40 percent in 2011 , to 45 percent in 2018 (European Commission 2019).

This article focuses on the influence of $\mathrm{HE}$ on the political participation of young adults (defined here as 18 to 24-year-olds) in the fifteen countries of the 'old' European Union (before Eastern enlargement in 2004 and the UK's withdrawal from the EU in January 2020). ${ }^{2}$ The article examines the impact of education both as a source of unequal participation (between young people in and out of education) and as an institutional support for students (from different backgrounds) - imparting skills and political understanding and providing opportunities for civic and political engagement in the key developmental stage of 'emerging adulthood' (Arnett 2004). Drawing on data from waves 1 to 8 of the European Social Survey (ESS), which is undertaken every two years, the article analyses these issues and reveals two 
significant new findings. First, not only does education matter, but being in education matters more than an individual's level of educational attainment for levels of civic and political participation. HE students (aged 18 to 24 ) are not only more politically active than their peers but are also more engaged than the average adult (across all age groups). Second, HE establishments seem to play an important role as social levellers: being in education neutralises differences between young people from high-income and low-income backgrounds with regards to such participation.

\section{Inequalities of Participation}

Democracy is widely defined as a form of government in which every citizen's views should count in decisions that affect their lives. The political theorist Robert Dahl (1971: 1), for example, wrote that 'a key characteristic of a democracy is the continuing responsiveness of the government to the preferences of its citizens, considered as political equals'. Yet in contemporary liberal democracies, the evidence clearly shows that wealthier and bettereducated citizens are more likely than less well-off and less well-educated citizens to have high levels of civic and political understanding, to vote in elections, and to give time and money to political campaigns (Grasso 2016; Marien et al. 2010; Sloam 2013).

A second key determinant of political engagement is age. Young people in most Western liberal democracies are participating less than previous generations of young people in electoral politics, in preference to alternative kinds of political engagement: from the ballot box, to demonstrations, to consumer action (Kyroglou \& Henn 2017; Norris and Inglehart 2019; Stolle et al. 2005). The arenas for their participation have also become more diverse: from political parties, to issue groups, to social movements, to online social networks (Bennett \& Segerberg 
2013; Della Porta \& Tarrow 2005). As electoral forms of political engagement and political structures are viewed as less appropriate for modern life, citizens have increasingly turned their focus from politics to policy - away from engagement with traditional political institutions and processes (such as political parties and elections), and instead towards specific policy concerns. Thus, young people can be characterised as 'standby citizens' who engage from time-to-time with political issues that hold meaning for their everyday lives (Amnå \& Ekman 2014). They are attracted to intermittent, non-institutionalised, issue-based, horizontal forms of engagement and repelled by the thought of long-term commitment through formal institutions with broader policy goals and entrenched hierarchies (Bang \& Esmark 2009; Henn et al. 2018; Tormey 2015). The school climate strikes, inspired by the Swedish activist Greta Thunberg, provided an optimal example of how a social movement can spread, with immense speed and intensity if it resonates with a younger audience (Pickard 2019).

Young Europeans have turned towards non-electoral forms of political engagement. But these forms of engagement are marked by large social inequalities based, for instance, on social class, income and educational career and qualifications (Marien et al. 2010; Norris et al. 2005; Sloam 2013). One explanation for these uneven patterns of participation might be that many nonelectoral forms of political participation require a high degree of expertise and social connectedness (Dalton 2004). For example, not everyone would have the self-confidence or knowledge of the system to speak to local officials about a failing school or to lobby their member of parliament about a threat to the local environment. It is not only the alternative modes of engagement that are marked by these inequalities, but also emerging arenas of engagement. The so-called 'digital divide' has received much attention in the academic literature (Mossberger et al. 2007), and it is a divide that is particularly noticeable between rich 
and poor, and between those with high and low levels of educational achievement (Grasso et al. 2017; Schlozman et al. 2010). Socio-economic status is, therefore, central in defining citizens' political participation. And educational attainment is crucial, in this context, as a marker of socio-economic status. But is education merely a proxy for socio-economic status? Or is there something more to the relationship? The existing literature offers us key insights into the link between education and political engagement.

\section{Education and Political Participation}

It has long been argued that education and educational establishments have an important role to play in fostering civic and political participation. Perhaps the most famous contribution to understanding the connection between education and democratic engagement was made by the American philosopher and educational reformer John Dewey, especially in his book Democracy and Education, first published in 1916 (see Steiner 1994). Dewey viewed education as part of his bigger project that included exploring the nature of experience, knowledge, society, ethics and aesthetics. He argued for the renewal of public, democratic life and placed a great deal of emphasis on the importance of deliberation, participation and communication. For Dewey (1959: 7), it is through these processes that citizens learn about democracy; by viewing themselves as social beings concerned with the common good - 'the very process of living together educates'. He argued that a desirable form of society is one in which all members can participate and communicate on equal terms, and where the education system facilitates such participation and promotes intelligent inquiry. 
For over fifty years, scholars have found that better educated citizens are more likely to vote in elections and participate in political campaigns (Parry et al. 1992; Verba \& Nie 1972; Verba et al. 1995), although some researchers view educational attainment as a proxy for the social status, cognitive abilities and personality traits of citizens (Berinsky \& Lenz 2011). Others believe that education improves the relevant skills of citizens, as well as increasing their interest in political issues and their sense of civic duty (Lewis-Beck et al. 2008; Verba et al. 1995; Wolfinger \& Rosenstone 1980). Further recent research suggests, in support of Dewey, that it is not just educational attainment levels that matter, but also the nature of an educational establishment, its 'democratic ethos', which has an important bearing on the likelihood of future democratic engagement (Flanagan \& Levine 2010; Kerr et al. 2007). It has, thus, been persuasively argued that educational establishments play a crucial cognitive and social role in the development of political understanding (Flanagan et al. 2007). They are sites of political and civic action, and arenas in which individuals develop their own personal political biographies (Flanagan \& Levine 2010; Keating 2014; Niemi \& Junn 1998). In the past, institutions like churches, trade unions and political parties provided opportunities for young people, in their transition to early adulthood, to get engaged in politics and in their communities. Today, however, much of that scaffolding is gone. In this context, universities and colleges, with their wide reach, play a more important role than ever (Goddard et al. 2016).

Although a considerable volume of literature exists on the development of citizenship education and active citizens across the different school systems of Europe (see, for example, Keating 2014; Schulz et al. 2010), hardly any attention has been paid to the role of HE beyond work on student mobilisation in elections and social movements (Sloam and Henn 2019). This contrasts sharply with the United States, where the presence of 'civic education' programmes 
in universities and colleges - where these are integrated into the curriculum through means such as service-learning (Gelmon et al. 2018; Longo et al. 2006) - increases volunteering on campuses (Pryor et al. 2008), and institutional support for and concrete commitments to the civic mission of HE are all well documented. Colby et al. (2003: 19) detail how programmes have been developed in a number of US institutions to 'build bridges to students' own conceptions of appropriate political analysis and action', and to illustrate how political issues relate to public policy and electoral politics. We also know from the US literature that it is not just citizenship education, volunteering and institutional support structures that foster student engagement, but also the existence of a participatory culture (civic and political engagement as a cultural norm) that motivates students to become politically active through a dense collection of social networks and student societies (Beaumont et al. 2006; Jacoby 2009).

Of course, not all young people go on to study at universities and colleges, but with such a substantial number now passing through HE establishments, universities and colleges have the potential to promote political participation amongst a significant proportion of citizens. They can act as 'mini-polities' (Flanagan et al. 2007), formative arenas for expression and civic engagement, for practice in social relations and in dealing with authority. This places great importance upon their democratic nature and the opportunities they provide for student expression. If educational establishments can help increase students' levels of 'personal efficacy' - their belief that they can understand and influence political issues and events, of having confidence in their democratic skills - it follows that this is likely to have a positive future impact upon civic and political engagement. This article therefore not only examines the advantages wealth and a good education give young people in terms of their democratic 
engagement, but also explores whether educational institutions can play a significant role in helping to reduce the disadvantages suffered in this regard by less wealthy students.

\section{Methods}

The existing literature provides strong evidence to support three claims. First, that young people are turning away from electoral forms of politics to new modes of engagement. Second, whilst being more youth-oriented than voting, these alternative modes of engagement tend to be dominated by the well-educated and the well-off. Third, education and educational establishments can play a key role in shaping civic and political engagement. Based on these claims, this article examines the influence of HE on political participation amongst young Europeans (here, 18 to 24-year-olds). The first part of the investigation leads us to consider the extent to which levels of educational attainment ${ }^{3}$ and having experienced HE (either currently enrolled or previously completed) or not, ${ }^{4}$ both matter for civic and political participation amongst young people and older adults (and in comparison with high-income and low-income groups $^{5}-$ see Table 1). The second phase of the analysis contrasts the political engagement of 18 to 24-year-olds who have experience of $\mathrm{HE}$ with those who do not (see Table 2). The final part of the study uses stepwise regression to consider young Europeans from low- and from high-income households, and how their political participation and political engagement may be impacted by their experiences of HE (Tables 3 and 4).

To investigate these issues, the article uses integrated data from waves 1 to $8^{6}$ of the European Social Survey (ESS, 2002-2016) across the fifteen member states of the old EU. The ESS is uniquely helpful in exploring youth participation in democracy across national boundaries. Firstly, it includes samples from all 28 countries of the EU, including the 'EU15' countries that 
form the focus of our analyses. Secondly, the ESS provides data on a very high number of young (18 to 24-year-old) respondents in the EU15 countries concerned $(\mathrm{N}=16,646)$. The large size of the ESS enables us to explore the political participation and political engagement of various sub-groups of 18 to 24-year-olds (such as by household income, educational attainment and status in education) without each of these falling to statistically insignificant levels. And, thirdly, the waves of the survey (taking place every two years) within a limited time frame cater for short-term distortions in the political environment, such as the demonstrations against the Iraq War. Other international surveys either only provide a one-off snapshot of youth participation (Van Deth et al. 2007) or provide data on only small samples of young adults over waves that are too far apart (the World Values Survey and European Values Study) or which focus on a very specific age range (Schulz et al. 2010).

Given the increasing turn by young people to non-electoral forms of political participation (described above), it would have been ideal to have analysed a wide range of different types of civic and political participation (see Pattie et al. 2004 and Van Deth et al. 2007 for extensive batteries of political action). With the ESS data, however, we were able to investigate seven forms of "political participation". Of these, three are classed as 'electoral participation' ('Voted [in the] last national election', 'Worked in a political party or action group', 'Contacted a politician or government official'). In addition, one can be considered an institutionalised, nonelectoral form of engagement ('Worked in another organisation or association' for a political cause). Finally, three that can be broadly categorised as issue-based forms of participation ('Signed a petition', 'Boycotted certain products', and 'Taken part in a lawful public demonstration'). The recent literature, which refers to 'standby citizens', 'engaged citizens' and 'critical citizens' (Amnå \& Ekman 2014; Dalton 2009; Norris 2011) suggests that it is 
important to explore the underlying issues of political interest, political understanding (personal efficacy), and social and political trust. With this in mind, we have selected four indicators of "political engagement". For the first of these, we recorded the percentage of (young) citizens who were 'very interested' or 'quite interested' in politics. Secondly, we calculated personal efficacy as the percentage of young Europeans who seldom or never found 'politics too complicated to understand'. Finally, we studied levels of social trust ('Most people can be trusted or that you can't be too careful in dealing with people') and political trust ('how much you personally trust [...] politicians'), both on an 11-point scale of 0 to 10 , where 0 was no trust and 10 was complete trust.

\section{Results}

Patterns of political participation and engagement

The data provide key insights into patterns of political participation and engagement amongst citizens across Europe. Table 1 confirms that whether or not people have opted to remain in education after reaching the age of 18 is the key predictor of political participation and political engagement. However, other factors such as educational attainment, age, and household income each have a noticeable impact.

European citizens aged 18 years or over who have formally engaged with HE (higher education), either as existing or previous students (column B), score considerably more highly on each of the political participation and political engagement items than the general adult population (M), or indeed any of the income, age or educational qualification groups. The data indicate that $83.1 \%$ of those who had experienced HE had voted. Four tenths had signed a 
petition (41.9\%), nearly a third had joined a boycott (31.2\%), while about a quarter had either worked for a political organisation or association other than a political party $(25.4 \%)$ or had engaged in contact activities with politicians or government officials (20.5\%). They also scored more highly than any of the other groups in terms of either participation in a lawful public demonstration $(15.9 \%)$ or in a political party or action group $(6.2 \%)$. Furthermore, their mean political engagement scores for trust (social, 5.5 out of 11; political 3.8 out of 11), political interest (2.9 out of 4) and political understanding (3.2 out of 5) are also higher than for the other groups listed in Table 1, and these mean differences are statistically significant. ${ }^{7}$ Column C considers the differences between people who have engaged with HE and those who have not. The data confirm that experience of HE has a consistently positive impact on all of the seven political participation items as well as all levels of political engagement - indicating that exposure to HE appears to have a transformative effect on European adults in terms of nurturing their democratic engagement.

Education is also important in terms of level of qualifications gained. Europeans aged 18 and above who had gained a level of qualifications necessary to enrol for HE study at some point in their lives (column G), were much more likely to participate in all seven political activities than those who had left school with lower level qualifications $(\mathrm{H})$. Their scores for the four political engagement items (social and political trust, political interest and political understanding) were also considerably higher, statistically significantly so. Column I records the scale of the political participation and political engagement gaps between these two groups.

Those from high-income backgrounds (column D) are more active than low-income groups (E) in terms of the various modes of political participation considered and also display statistically 
significantly higher levels of political engagement (social and political trust, political interest and personal efficacy). Nonetheless, these income variations $(\mathrm{F})$ are less marked than are those differences observed for the attended/not attended HE variable (C) and the educational qualifications variable (I). The exception is voting, where the income-voting gap (F) is 9.7\%, which is higher for the HE-voting gap (C) and the qualifications-voting gap (I).

What is also apparent from these data is that young (18 to 24-year-old) adults (column J) are typically less active in different electoral and non-electoral/issue-based forms of participation than are their older contemporaries (K). The only exceptions are that they are only marginally less likely to have signed a petition, and they have a noticeably greater likelihood to have joined lawful demonstrations in the past. Furthermore, the age differences with respect to political engagement are statistically significant. However, while younger citizens display less political interest and lower levels of political understanding than their older counterparts, they have greater levels of social and political trust.

\section{TABLE 1 ABOUT HERE}

The importance of an individual having engaged with HE (either as a current student or as a previous student) is particularly obvious when we focus on young adults aged 18-24. Table 2 explores in more detail the impact of this variable on youth political participation and political engagement. Here, we can see that young Europeans having engaged with HE (column A) are much more active across all (electoral-institutional and non-institutional) forms of participation than their peers who have successfully completed their secondary school education but are no 
longer in education (B). Furthermore, engaging with HE seems to have a statistically significant and positive impact in terms of their levels of political engagement - political and social trust as well as political interest and personal efficacy. These results offer a clear indication that being in HE matters in terms of positively structuring young people's political participation and political engagement, a finding which is consistent with other recent research (Henn and Foard 2014).

\section{TABLE 2 ABOUT HERE}

Given the large social inequalities in many issue-based, non-electoral forms of political participation (and in electoral participation in several countries), it is also important to consider the extent to which being in education matters for young people from low-income backgrounds. The sample sizes for these groups are relatively small because household income is not tested in all waves or in all EU15 countries in the ESS data, and we are only focussing on the upperand lower- quartile income groups. As a consequence, the following results should be treated with some degree of caution. Nevertheless, the findings are dramatic. Young low-income HE students (past and present, column D) are significantly more politically active and engaged than their low-income peers who have completed their secondary schooling but not progressed to HE (column E). This is the especially the case for voting (66.9\% to $20.8 \%$ ) but also for the other items including contact with politicians or government officials (10\% to $4.5 \%)$, working for a party (6.1 to 0$),{ }^{8}$ working with non-party organisations ( $15.6 \%$ to $\left.5.1 \%\right)$, signing petitions ( $40.7 \%$ to $10.2 \%)$, taking part in demonstrations ( $27.7 \%$ to $7.6 \%)$ and boycotting products for political ends (35.2\% to $7.1 \%)$. There are statistically significant differences between the two groups in terms of political engagement, with low-income students scoring considerably more 
highly than low-income non-students in terms of social and political trust, levels of interest in politics and political understanding.

Intriguingly, progressing to $\mathrm{HE}$ appears to have a more significant impact on young people from low-income backgrounds than it does on high-income students in terms of several aspects of political participation and political engagement. As we might expect, the data indicates that young high-income HE college students (column G) were more likely to have taken part in various forms of political action than were high-income youth who had left education after completing secondary school (column $\mathrm{H}$ ). This is the case for all of the seven modes of political participation considered in Table 2. Furthermore, all of the political engagement differences are statistically significant. However, the political participation and political engagement gaps for low-income students and low-income non-students (column F) are in most cases considerably higher than for the high-income students/non-students (column I).

Interestingly, the relationship between income and political participation reported for $\mathrm{HE}$ students (and past students) is the reverse of what is present in Table 1 for the general adult population. For European citizens of all ages, high-income adults have greater levels of political participation and political engagement (on all items) than low-income citizens. However, the opposite is the case when considering the findings in Table 2 for young people aged 18-24. The first point to make is that in terms of the four political engagement variables, Table 2 offers no evidence of any appreciable difference between the low-income student group (column D) and their high-income contemporaries (column G). However, low-income HE students (column D) are generally more politically active than high-income HE students (G). The only exception is for the 'working with non-party organisations' item, although here the 
difference is marginal (low-income 15.6\%: high-income 16\%). This indicates that experiencing HE has a higher positive impact on the political participation of low-income youth than it does on high-income youth - it reverses the income gap observed for the general European adult population.

We can explore the transformative power of being in HE on European 18-24-year-olds from different income groups by considering the gaps in political participation and in political engagement between students and non-students from low-income backgrounds (column F), and comparing those with the differences between students and non-students with high-income circumstances (column I). The findings indicate that the participation gap between students and non-students is actually greater for low-income youth than it is for high-income youth for all of the seven participation items. This suggests that for all forms of political participation considered in Table 2, progressing to HE after secondary schooling has a much larger positive impact on young people from low-income backgrounds than it does on their peers from highincome backgrounds. This pattern is not reproduced for the political engagement items. The only political engagement gap is for the political trust variable, with the difference in the mean trust score between low-income students and non-students (see column F) marginally higher (mean=0.6) than for the high-income student/non-student groups (column I, mean=0.3).

The data in Table 2 also allow us to consider the extent to which remaining in education after secondary school impacts on the patterns of political participation and political engagement for those young people holding high level qualifications. The findings suggest that these highly qualified students will be slightly more likely to participate in different forms of political activity if they choose to enter HE (column J) compared to similarly qualified youth who have left education (column K). Furthermore, remaining in education has a statistically significant 
effect on political engagement; highly qualified young people progressing to HE are considerably more likely to report high levels of social and politic trust, political interest and personal efficacy than are other highly qualified youth who do not enter HE. The scale of the political participation and political engagement gaps between highly qualified young people who have engaged with HE compared with those who have not, is summarised in column L.

The impact of progressing to Higher Education

The analyses so far indicate that engaging with HE (as an existing or former student) has a stronger and more transformative impact on the patterns of political participation for lowincome European youth than it does for young students from high-income backgrounds. Using stepwise regression analyses, we are able to examine this effect further by testing for the impact of engaging with $\mathrm{HE}$ on the seven selected political participation variables as well as the four political engagement variables of social trust, political trust, political interest and personal efficacy (political understanding). ${ }^{9}$ In doing so, we control for levels of educational attainment and household income. Existing studies suggest that gender (Furlong \& Cartmel 2012; Norris \& Inglehart 2009) and ethnicity (Heath et al. 2011) may also impact on political participation and political engagement, and therefore we also control for these two demographic characteristics. $^{10}$

In Table 3, we consider European youth who left education after completing their secondary school studies and who do not progress on to HE. With the exception of the two items, "working for a party or action group", and "participation in lawful public demonstration", Model 1 indicates that educational attainment has a statistically significant predictive relationship on the majority of the political participation variables. Those with higher 
educational qualifications are more likely than their less qualified counterparts to take part in those five political actions. The pattern differs somewhat when it comes to the four political engagement variables; here, statistically significant differences are evident only for political interest and personal efficacy, with those holding higher level qualifications more likely to display lower levels political interest but higher political understanding/personal efficacy than the group of less qualified youth.

Income has less of a structuring predictive impact than does educational attainment. However, those from the highest income band who have not engaged with HE are more predisposed to vote, to work for a party or action group, to sign a petition and to report higher social trust and interest in politics than is the case for non-students from a low-income background.

Model 2 in Table 3 presents the more powerful full model for reported political participation and political engagement, now including gender and ethnicity. The data suggest that for these particular young people, both gender and ethnicity have a statistically significant predictive impact on many of the political participation and political engagement variables. Even taking into account the effects of these two demographic variables, the analyses reveal that household income and especially educational attainment continue to remain statistically significant predictors of several aspects of political engagement and political participation. The only differences are that introducing gender and ethnicity into the model have the following effects. Educational attainment no longer exerts a statistically significant impact on the boycotting variable. Additionally, a new predictive impact is introduced in that those with higher qualifications have less political trust than other youth, while the effects on levels of political interest and personal efficacy are reversed from Model 1 . The only changed relationship for 
income is that high-income groups are now statistically significantly more likely to express an interest in politics than are youth from comparatively lower income backgrounds.

\section{TABLE 3 ABOUT HERE}

Table 4 focuses on those young people who have opted to continue beyond secondary school and into HE. Continuing education seems to have an important impact on those with different levels of educational attainment with respect to three of the political participation variables those with higher educational attainment remain significantly more likely to vote, to work for a party or action group and also to sign petitions on reaching HE. This same group is more likely to be interested in politics and to have higher personal efficacy, statistically significantly so. The introduction of gender and ethnicity does not impact on these relationships in any appreciable ways.

Intriguingly, the findings in Model 1 indicate that low-income students are actually more likely than their high-income counterparts to sign a petition, join a boycott and take part in a demonstration. In contrast, Model 1 of Table 3 (that includes only young people who had left education), reveals no such predictive relationships. Of additional importance, although Table 3 indicates that low-income youth leaving education after secondary school vote, sign petitions and work for parties and political action groups at considerably lower rates than high-income school leavers, Table 4 indicates that these three political participation gaps - as well as their depressed levels of social trust - disappear if low-income youths engage with HE. Furthermore, new impacts are evident; unlike low-income school leavers, low-income students have 
significantly higher levels of political interest and political trust than do high-income students. Taken together, these results suggest that HE has more of a transformational impact for lowincome students in terms of several of the political participation and political engagement variables than is the case for students from high-income backgrounds.

Model 2 indicates that gender and ethnicity have a statistically strong bearing on many aspects of students' political participation and political engagement. However, even controlling for these two effects, there is no evidence of any diminishing effect of income. Low-income HE students remain considerably more likely than their high-income counterparts to take part in boycotting, demonstrating and petitioning for political purposes. Such political activity is not evident within the low-income non-HE youth group (Table 3 ). This suggests that joining HE is associated with an upsurge in these political activities by low-income youth when compared with high-income students. Furthermore, negating the findings in Table 3, these young students from low-income households are no longer less likely to vote or to work for a party or action group, and no longer more distrustful of politicians, than are high-income students. Indeed, they actually express higher levels of political interest and political trust than high-income students. In combination, these results suggest that HE has the outcome of reversing the effect of household income on five of the seven forms of political participation and on two of the four political engagement variables as identified across the wider adult European population (Table 1) and for non-HE young people (Table 3).

\section{TABLE 4 ABOUT HERE}




\section{Discussion and conclusion}

This research adds empirical weight to the theoretical arguments considered earlier in the article linking education and democracy. Utilising the European Social Survey (ESS), the research findings are significant in drawing attention to the importance of HE, over and above social class, as a key determinant of civic and political participation by young people. This calls into question a simple linking of educational attainment and social status. Simply being in $H E$ boosts young people's civic and political participation, thereby helping to neutralise the differences between high-income and low-income groups. The findings therefore run counter to the arguments of those who have put forward the case that education does not have a direct causal effect on political participation, being only a proxy for other factors, such as cognitive ability and family socio-economic status (Berinsky \& Lenz 2011; Campbell 2009; Kam \& Palmer 2008).

The results from this study indicate that HE is particularly important in scaffolding youth transition into adulthood through political socialisation, providing significant opportunities for participation for young people, inculcating them into a culture of participation through social networks. Young people in (or having completed) HE are very engaged in each of the various forms of civic and political participation as compared to the general population, including voting. Present and former HE students are also considerably more active than young people who do not progress to higher education. However, the findings also show that there are large social inequalities of participation. For example, only a minority (20.8\%) of young people from low-income groups who do not go into HE turnout to vote in national elections, and they have low levels of participation across the board. HE establishments seem to play an important role 
as social levellers. That is to say, experiencing higher education counteracts differences between young people from high-income and low-income backgrounds, ${ }^{11}$ leading to a huge difference in levels of civic and political participation between low-income young people in HE and low-income young people not in HE.

These findings point to the pivotal role of higher educational establishments in providing political socialisation for citizens in their transition to adulthood. Research suggests that during this transition period, young people are particularly open to new ideas, and that patterns of participation (or non-participation) established in these years are likely to last for life (Franklin 2004). Moreover, as noted above, institutions can play a vital role in fostering civic and political engagement by increasing the knowledge and skills of the less privileged to enable them to participate. In particular, universities and HE colleges can help neutralise social disadvantage and foster democratic engagement (Flanagan \& Levine 2010; Jennings \& Stoker 2004). Flanagan et al. (2012: 29) highlight the 'institutional lacuna' that exists in established democracies; in other words, the gap that has opened up as a result of the decline of political parties, trade unions and other traditional organisations of political socialisation, particularly for young people who do not go on to HE. This also helps to explain why educational achievement is so much more important than household income in determining youth civic and political engagement.

Dewey's arguments about the close links between education and democracy are therefore more relevant than ever. What type of participation should universities and colleges try to promote? Since young people are particularly attracted to non-electoral forms of participation, the evidence suggests they are likely to be more successful in promoting these forms of activity. 
On the other hand, if low levels of youth electoral participation ought to be regarded as a significant concern (which we think they should - not least because it leaves the way open for parties to neglect issues of particular importance to young people), then HE establishments have a part to play in encouraging formal participation, such as voting, too. Although the public policy agenda is quite advanced in school systems - we have seen great progress in the development of citizenship education in Europe over the past two decades - there is little improvement in this regard in universities and colleges.

Personal efficacy plays a key role in actualizing young people's politics. Here, the political literacy, democratic skills, and self-confidence of young citizens are of fundamental importance. In this respect, education and schooling is an essential prelude to participation (Pasek et al. 2008). Politically literate citizens are more likely to participate in democracy, and schools and universities play an important role in preparing young people for democratic life (Flanagan \& Levine 2010; Levinson 2010). In order for citizenship education to be delivered effectively, the culture of educational establishments - whether schools, colleges or universities - needs to reflect a democratic ethos in which students are actively involved in decision-making processes. HE institutions can and should (and many already do) allow students to participate in making decisions that affect them. By doing so, not only can such organisations enable students to develop decision-making skills, but also by participating in the life of the institution they can learn individual responsibility and gain valuable experience of working with others with alternative perspectives, skills and experiences, which is essential for democratic engagement. Moreover, our claim that being in HE has an independent (positive) effect on civic and political engagement through social networks and a culture of participation underpinned by a supportive institutional culture, is consistent with other research. For example, the 
Citizenship Education Longitudinal Study in England (Keating et al. 2010) and the International Association for the Evaluation of Educational Achievement comparative studies (Schulz et al. 2010) emphasize the importance of a school's 'democratic ethos'.

In summary, we draw two main conclusions from our analysis of the ESS data. First, HE institutions play a vital role in scaffolding the transition of young people into adulthood by providing them with opportunities to engage in forms of civic and political activity and immersing them in a strong participatory culture. And second, HE establishments can act as social levellers, as they are particularly effective in providing a platform for civic and political engagement for young people from deprived backgrounds. In our view, this places added emphasis on the role of HE in nurturing such engagement. We strongly believe that more research is needed - of a qualitative and longitudinal nature - to explore the mechanisms through which universities generate civic and political engagement amongst their students, and how this might be replicated in other social institutions. 
Table 1. Political participation and political engagement of people aged 18 years and over in the European Union $(\mathrm{EU15})(\mathrm{N}=197,924)$

\begin{tabular}{|c|c|c|c|c|c|c|c|c|c|c|c|c|c|}
\hline & $\begin{array}{c}\text { A: Not } \\
\text { engaged with } \\
\text { HE (all ages) } \\
\mathrm{N}=124,306\end{array}$ & $\begin{array}{c}\text { B: } \mathrm{In} / \\
\text { completed } \\
\text { HE (all } \\
\text { ages) } \\
\mathrm{N}=55,710\end{array}$ & $\begin{array}{l}\text { C: Whether } \\
\text { engaged } \\
\text { with } \mathrm{HE} \\
\text { gap }\end{array}$ & $\begin{array}{l}\text { D: High } \\
\text { Income } \\
\text { (all ages) } \\
\mathrm{N}=71,805\end{array}$ & $\begin{array}{c}\text { E: Low } \\
\text { Income } \\
\text { (all ages) } \\
\mathrm{N}=35,591\end{array}$ & $\begin{array}{c}\text { F: } \\
\text { Income } \\
\text { gap }\end{array}$ & $\begin{array}{c}\text { G: High } \\
\text { education } \\
\text { qualifs (all } \\
\text { ages) } \\
\mathrm{N}=127620\end{array}$ & $\begin{array}{c}\text { H: Low } \\
\text { education } \\
\text { qualifs } \\
\text { (all ages) } \\
\mathrm{N}=75265\end{array}$ & $\begin{array}{c}\text { I: } \\
\text { Qualifs } \\
\text { gap }\end{array}$ & $\begin{array}{c}\mathbf{J}: 18-24 \\
\text { year olds } \\
\mathrm{N}= \\
18,052\end{array}$ & $\begin{array}{c}\text { K: Aged } 25 \\
\text { plus } \\
\mathrm{N}=179,872\end{array}$ & $\begin{array}{l}\text { L: Age } \\
\text { Gap }\end{array}$ & $\begin{array}{c}\text { M: All } \\
\text { ages } \\
\mathrm{N}= \\
197,924\end{array}$ \\
\hline $\begin{array}{l}\text { Voted [in the] last national } \\
\text { election }\end{array}$ & 76.9 & 83.1 & -6.2 & 81.0 & 71.3 & 9.7 & 81.6 & 73.9 & 7.7 & 60.3 & 80.3 & -20 & 72.6 \\
\hline $\begin{array}{l}\text { Worked in a political party or } \\
\text { action group }\end{array}$ & 3.1 & 6.2 & -3.1 & 4.4 & 3.2 & 1.2 & 5.0 & 2.5 & 2.5 & 3.2 & 4.1 & -1.1 & 4 \\
\hline $\begin{array}{l}\text { Contacted a politician or } \\
\text { government official }\end{array}$ & 12.2 & 20.5 & -8.3 & 16.1 & 11.9 & 4.2 & 17.8 & 9.6 & 8.2 & 8.4 & 15.5 & -7.1 & 14.7 \\
\hline $\begin{array}{l}\text { Worked in another organisation } \\
\text { or association }\end{array}$ & 13.1 & 25.4 & -12.3 & 18.5 & 12.5 & 6.0 & 21.7 & 9.3 & 12.4 & 15.5 & 17.1 & -1.6 & 16.9 \\
\hline Signed a petition & 23.6 & 41.9 & -18.3 & 30.7 & 23.1 & 7.6 & 36.1 & 18.7 & 17.4 & 29.3 & 29.6 & -0.3 & 29.4 \\
\hline $\begin{array}{l}\text { Taken part in a lawful public } \\
\text { demonstration }\end{array}$ & 7.5 & 15.9 & -8.4 & 10.3 & 8.7 & 1.6 & 12.1 & 6.7 & 5.4 & 15.0 & 9.4 & 5.6 & 10 \\
\hline Boycotted certain products & 17.5 & 31.2 & -13.7 & 23.1 & 17.9 & 5.2 & 27.9 & 12.2 & 15.7 & 16.1 & 22.7 & -6.6 & 21.9 \\
\hline Trust (social) 0-10 (0 least) & 4.7 & 5.5 & $-0.8^{*}$ & 5.1 & 4.6 & $0.5^{*}$ & 5.2 & 4.5 & $0.7^{*}$ & 5.0 & 4.9 & $0.1^{*}$ & 5.0 \\
\hline Trust (politicians) $0-10$ (0 least) & 3.2 & 3.8 & $-0.6^{*}$ & 3.5 & 3.1 & $0.4^{*}$ & 3.6 & 3.2 & $0.4^{*}$ & 3.6 & 3.4 & $0.2 *$ & 3.4 \\
\hline Political interest 1-4 (1 Least) & 2.7 & 2.9 & $-0.2^{*}$ & 2.8 & 2.7 & $0.1^{*}$ & 2.8 & 2.6 & $0.2 *$ & 2.6 & 2.8 & $-0.2 *$ & 2.8 \\
\hline $\begin{array}{l}\text { Political understanding 1-5 (1 } \\
\text { Least) }\end{array}$ & 2.7 & 3.2 & $-0.5^{*}$ & 2.9 & 2.6 & $0.3^{*}$ & 3.1 & 2.5 & $0.6^{*}$ & 2.8 & 2.9 & $-0.1^{*}$ & 2.8 \\
\hline
\end{tabular}

Source: European Social Survey (waves 1-8)

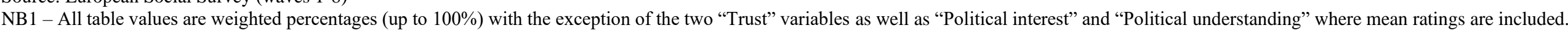

NB2 - All data are weighted. The ESS user guide states that unweighted $\mathrm{N}$ is an unreliable measure; therefore, percentages for all categories are reported but N is not reported

(www.europeansocialsurvey.org/docs/methodology/ESS_weighting_data_1.pdf)

NB3 - The analyses use the recommended combination of PSPWGHT and PWEIGHT as per the ESS guidelines (www.europeansocialsurvey.org/docs/methodology/ESS weighting data 1.pdf)

NB4 - Standard errors are only viable for the two "Trust" variables as well as "Political interest" and "Political understanding" which use means. Significant differences are reported as * $(p<.001)$ 
Table 2. Political participation and political engagement of 18-24-year olds in the European Union (EU15) $(\mathrm{N}=16,646)$

\begin{tabular}{|c|c|c|c|c|c|c|c|c|c|c|c|c|c|}
\hline & $\begin{array}{c}\mathbf{A}: \mathrm{In} / \\
\text { completed } \\
\mathrm{HE} \\
\mathrm{N}=10,159^{\#}\end{array}$ & $\begin{array}{c}\text { B: Not } \\
\text { engaged with } \\
\text { HE } \\
\mathrm{N}=6487^{\#}\end{array}$ & $\begin{array}{c}\text { C: } \\
\text { Whether } \\
\text { engaged } \\
\text { with HE } \\
\text { gap }\end{array}$ & $\begin{array}{c}\text { D: In/ } \\
\text { completed } \\
\text { HE (low } \\
\text { income) } \\
\mathrm{N}=302^{\#}\end{array}$ & $\begin{array}{c}\text { E: Not } \\
\text { engaged with } \\
\text { HE (low } \\
\text { income) } \\
\mathrm{N}=145^{\#}\end{array}$ & $\begin{array}{c}\text { F: Low } \\
\text { income gap } \\
- \\
\text { engaged/not } \\
\text { engaged } \\
\text { with HE }\end{array}$ & $\begin{array}{c}\text { G: } \mathrm{In} / \\
\text { completed } \\
\text { HE (high } \\
\text { income) } \\
\mathrm{N}=1,800^{\#}\end{array}$ & $\begin{array}{c}\text { H: Not } \\
\text { engaged with } \\
\text { HE (high } \\
\text { income) } \\
\mathrm{N}=1,077^{\#}\end{array}$ & $\begin{array}{c}\text { I: High } \\
\text { income gap } \\
- \\
\text { engaged/not } \\
\text { engaged } \\
\text { with HE }\end{array}$ & $\begin{array}{c}\mathbf{J}: \mathrm{In} / \\
\text { completed HE } \\
\text { (high qualifs) } \\
\mathrm{N}=7,593^{\#}\end{array}$ & $\begin{array}{c}\text { K: Not } \\
\text { engaged with } \\
\text { HE (high } \\
\text { qualifs) } \\
\mathrm{N}=4,313^{\#}\end{array}$ & $\begin{array}{c}\text { L: High } \\
\text { Qualifics } \\
\text { gap - } \\
\text { engaged/not } \\
\text { engaged } \\
\text { with HE }\end{array}$ & $\begin{array}{c}\text { M: } 18-24 \text { 's } \\
N= \\
16,646^{\#} \\
\end{array}$ \\
\hline $\begin{array}{l}\text { Voted [in the] last national } \\
\text { election }\end{array}$ & 65.8 & 55.2 & 10.6 & 66.9 & 20.8 & 46.1 & 66.4 & 57.5 & 8.9 & 68.8 & 61.8 & 7.0 & 40.6 \\
\hline $\begin{array}{l}\text { Worked in a political party } \\
\text { or action group }\end{array}$ & 3.9 & 2.3 & 1.6 & 6.1 & 0.0 & 6.1 & 3.5 & 2.8 & 0.7 & 4.1 & 2.5 & 1.6 & 3.2 \\
\hline $\begin{array}{l}\text { Contacted a politician or } \\
\text { government official }\end{array}$ & 9.3 & 6.8 & 2.5 & 10.0 & 4.5 & 5.5 & 8.4 & 6.0 & 2.4 & 10.1 & 7.9 & 2.2 & 8.4 \\
\hline $\begin{array}{l}\text { Worked in another } \\
\text { organisation or association }\end{array}$ & 19.2 & 10.6 & 8.6 & 15.6 & 5.1 & 10.5 & 16.0 & 7.5 & 8.5 & 19.3 & 12.8 & 6.5 & 15.5 \\
\hline Signed a petition & 34.7 & 21.5 & 13.2 & 40.7 & 10.2 & 30.5 & 29.9 & 19.4 & 10.5 & 37.5 & 25.5 & 12.0 & 29.2 \\
\hline $\begin{array}{l}\text { Taken part in a lawful } \\
\text { public demonstration }\end{array}$ & 19.4 & 9.3 & 10.1 & 27.7 & 7.6 & 20.1 & 20.4 & 8.6 & 11.7 & 19.6 & 10.9 & 8.7 & 15.0 \\
\hline Boycotted certain products & 19.4 & 11.6 & 7.8 & 35.2 & 7.1 & 28.1 & 15.4 & 8.8 & 6.6 & 20.4 & 14.3 & 6.1 & 16.0 \\
\hline Trust (social) 0-10 (0 least) & 5.3 & 4.7 & $0.6^{*}$ & 5.3 & 4.7 & $0.6^{*}$ & 5.3 & 4.7 & $0.6^{*}$ & 5.4 & 4.8 & $0.6^{*}$ & 5.0 \\
\hline $\begin{array}{l}\text { Trust (politicians) } 0-10(0 \\
\text { least) }\end{array}$ & 3.9 & 3.3 & $0.6^{*}$ & 3.9 & 3.3 & $0.6^{*}$ & 3.8 & 3.5 & $0.3^{*}$ & 3.9 & 3.4 & $0.5^{*}$ & 3.6 \\
\hline $\begin{array}{l}\text { Political interest 1-4 (1 } \\
\text { Least) }\end{array}$ & 2.4 & 2.1 & $0.3^{*}$ & 2.4 & 2.1 & $0.3^{*}$ & 2.3 & 2.0 & $0.3^{*}$ & 2.4 & 2.2 & $0.2^{*}$ & 2.2 \\
\hline $\begin{array}{l}\text { Political understanding } 1-5 \\
\text { (1 Least) }\end{array}$ & 2.8 & 2.6 & $0.2 *$ & 2.8 & 2.6 & $0.2 *$ & 2.8 & 2.6 & $0.2 *$ & 2.9 & 2.7 & $0.2 *$ & 2.8 \\
\hline
\end{tabular}

Source: European Social Survey (waves 1-8)

${ }^{\#} \mathrm{~N}$ reflects sample composition and does not represent the actual figures for European countries

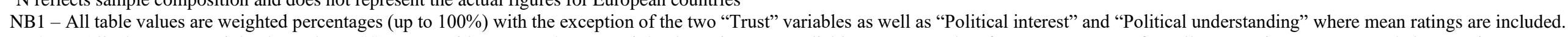

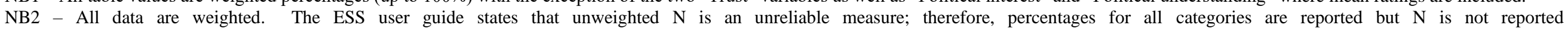
(www.europeansocialsurvey.org/docs/methodology/ESS_weighting data_1.pdf)

NB3 - The analyses use the recommended combination of PSPWGHT and PWEIGHT as per the ESS guidelines (www.europeansocialsurvey.org/docs/methodology/ESS weighting data 1.pdf)

NB4 - Standard errors are only viable for the two "Trust" variables as well as "Political interest" and "Political understanding" which use means. Significant differences are reported as * $(\mathrm{p}<.001)$ 
Table 3. Comparative results for 2 stepwise regression models for 18-24-year olds not progressing to Higher Education (HE) - the impact of income, educational attainment, gender and ethnicity on political participation and political engagement $(\mathrm{N}=6,487)$

\begin{tabular}{|c|c|c|c|c|c|c|c|c|c|c|c|}
\hline & $\begin{array}{c}\text { Vote last } \\
\text { national } \\
\text { election } \\
\mathrm{N}=5,043\end{array}$ & $\begin{array}{l}\text { Working for a } \\
\text { party or action } \\
\text { group } \\
\mathrm{N}=6,469\end{array}$ & $\begin{array}{c}\text { Contacting } \\
\text { politician or } \\
\text { government } \\
\text { official } \\
\mathrm{N}=6,460\end{array}$ & $\begin{array}{c}\text { Working for } \\
\text { non-party } \\
\text { political } \\
\text { organisation } \\
\mathrm{N}=6,468\end{array}$ & $\begin{array}{l}\text { Signing a petitiol } \\
\qquad N=6,460\end{array}$ & $\begin{array}{l}\text { Participation in } \\
\text { lawful public } \\
\text { demonstration } \\
\mathrm{N}=6,467\end{array}$ & $\begin{array}{c}\begin{array}{c}\text { Joining a } \\
\text { boycott }\end{array} \\
\mathrm{N}=6,447\end{array}$ & $\begin{array}{c}\text { Trust (social) } \\
0-10 \text { (0 least) } \\
\mathrm{N}=6,469\end{array}$ & $\begin{array}{c}\text { Trust (political) } \\
0-10 \text { (0 least) } \\
\mathrm{N}=6,469\end{array}$ & $\begin{array}{c}\text { Political } \\
\text { interest } \\
\mathrm{N}=6.469\end{array}$ & $\begin{array}{l}\text { Personal } \\
\text { efficacy } \\
\mathrm{N}=3748\end{array}$ \\
\hline \multicolumn{12}{|c|}{ Model 1 - Gender \& Ethnicity not included } \\
\hline Income & $-.215(2) * * *$ & $-.056^{*}$ & n.s. & n.s. & $-.069(2)^{* *}$ & n.s. & n.s. & $.109 * * *$ & n.s. & $.064(2)^{* *}$ & n.s. \\
\hline \multirow[t]{2}{*}{$\begin{array}{l}\text { Educational } \\
\text { attainment }\end{array}$} & $-.217(1)^{* * *}$ & n.s. & $-.065^{* *}$ & $-.065^{* *}$ & $-.081(1)^{* * *}$ & n.s. & -.067 & n.s. & n.s. & $-.137(1)^{* * *}$ & $.051 *$ \\
\hline & $\mathrm{R}^{2}=.104$ & $\mathrm{R}^{2}=.003$ & $\mathrm{R}^{2}=.004$ & $\mathrm{R}^{2}=.004$ & $\mathrm{R}^{2}=.013$ & $\mathrm{R}^{2}=$ & $\mathrm{R}^{2}=.005$ & $\mathrm{R}^{2}=.012$ & $\mathrm{R}^{2}=$ & $\mathrm{R}^{2}=.025$ & $\mathrm{R}^{2}=.003$ \\
\hline \multicolumn{12}{|c|}{ Model 2 - All named variables included } \\
\hline Income & $-.219(1)^{* * *}$ & $-.056(2)^{*}$ & n.s. & n.s. & $-.070(2)^{* *}$ & n.s. & n.s. & $.105(1)^{*}$ & n.s. & n.s. & n.s. \\
\hline $\begin{array}{l}\text { Educational } \\
\text { attainment }\end{array}$ & $-.196(2)^{* * *}$ & n.s. & $-.068(1)^{* *}$ & $-.063^{* *}$ & $-.075(1)^{* *}$ & n.s. & n.s. & n.s. & $-.054(3)^{*}$ & $.135(1)^{* * *}$ & $-.054(3)^{*}$ \\
\hline Gender & n.s. & $-.067(1)^{* *}$ & n.s. & n.s. & $-.075(3)^{* *}$ & n.s. & $-.078(1)^{* *}$ & $-.072(2)^{* *}$ & $.222(1)^{* * *}$ & $-.076(2)^{* *}$ & $-.222(1)^{* * *}$ \\
\hline Ethnicity & $-.099(3)^{* * * *}$ & n.s. & $.064(2)^{* *}$ & n.s. & $-.059(4)^{*}$ & n.s. & $-.064(2)^{* *}$ & n.s. & $-.072(2)^{* *}$ & $.061(3)^{*}$ & $.072(2)^{* *}$ \\
\hline & $\mathrm{R}^{2}=.109$ & $\mathrm{R}^{2}=.008$ & $\mathrm{R}^{2}=.008$ & $\mathrm{R}^{2}=.004$ & $\mathrm{R}^{2}=.018$ & $\mathrm{R}^{2}=$ & $\mathrm{R}^{2}=.010$ & $\mathrm{R}^{2}=.016$ & $\mathrm{R}^{2}=.061$ & $\mathrm{R}^{2}=.029$ & $\mathrm{R}^{2}=.061$ \\
\hline
\end{tabular}

Source: European Social Survey (waves 1-8). All values are Beta Coefficients and statistically significant $* * *=(p \leq .001) . * *=p \leq .01 . *=p \leq .05$ Values in brackets are the predictor order.

NB - "n.s." indicates non-significant relationships

NB2 - The analyses use the recommended combination of PSPWGHT and PWEIGHT as per the ESS guidelines (www.europeansocialsurvey.org/docs/methodology/ESS_weighting_data_1.pdf) 
Table 4. Results for stepwise regression model for 18-24-year olds progressing to Higher Education (HE) - the impact of income, educational attainment, gender and ethnicity on political participation and political engagement $(\mathrm{N}=10,159)$

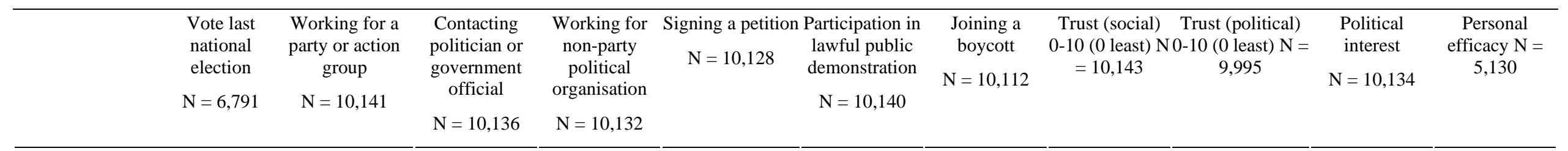

Model 1 - Gender \& Ethnicity not included

\begin{tabular}{|c|c|c|c|c|c|c|c|c|c|c|c|}
\hline Income & n.s. & n.s. & n.s. & n.s. & $.060(2)^{* *}$ & $.050 * *$ & $.150 * * *$ & n.s. & $-.062 * *$ & $-.091(1)^{* * *}$ & n.s. \\
\hline $\begin{array}{l}\text { Educational } \\
\text { attainment }\end{array}$ & $-.160 * * *$ & $-.055^{* *}$ & n.s. & n.s. & $-.081(1)^{* * *}$ & n.s. & n.s. & n.s. & n.s. & $.069(2)^{* * *}$ & $.063 * * *$ \\
\hline & $\mathrm{R}^{2}=.026$ & $\mathrm{R}^{2}=.003$ & $\mathrm{R}^{2}=$ & $\mathrm{R}^{2}=$ & $\mathrm{R}^{2}=.011$ & $\mathrm{R}^{2}=.003$ & $\mathrm{R}^{2}=.022$ & $\mathrm{R}^{2}=$ & $\mathrm{R}^{2}=.004$ & $\mathrm{R}^{2}=.014$ & $\mathrm{R}^{2}=.004$ \\
\hline
\end{tabular}

Model 2 - All named variables included

\begin{tabular}{|c|c|c|c|c|c|c|c|c|c|c|c|}
\hline Income & n.s. & n.s. & n.s. & n.s. & $.060(2)^{* *}$ & $.055 * *$ & $.152(1)^{* * * *}$ & n.s. & $-.073(3) * * *$ & $-.091(2) * * *$ & n.s. \\
\hline $\begin{array}{l}\text { Educational } \\
\text { attainment }\end{array}$ & $-.160 * * *$ & $-.063(2)^{* * *}$ & n.s. & n.s. & $-.082(1)^{* * *}$ & n.s. & n.s. & n.s. & n.s. & $.080(3)^{* * *}$ & $.075(2) * * *$ \\
\hline Gender & n.s. & $.063(1)^{* * *}$ & n.s. & n.s. & n.s. & n.s. & $-.065(2) * * *$ & $-.054(2) * *$ & $-.110(2)^{* * *}$ & $-.109(1) * * *$ & $-.184(1) * * *$ \\
\hline Ethnicity & n.s. & n.s. & $-.065 * * *$ & $-.066 * * *$ & $.040(3)^{* * *}$ & n.s. & n.s. & $.177(1)^{* * *}$ & $.142(1)^{* * *}$ & n.s. & n.s. \\
\hline & $\mathrm{R}^{2}=.026$ & $\mathrm{R}^{2}=.007$ & $\mathrm{R}^{2}=.004$ & $\mathrm{R}^{2}=.004$ & $\mathrm{R}^{2}=.013$ & $\mathrm{R}^{2}=.003$ & $\mathrm{R}^{2}=.028$ & $\mathrm{R}^{2}=.034$ & $\mathrm{R}^{2}=.035$ & $\mathrm{R}^{2}=.026$ & $\mathrm{R}^{2}=.038$ \\
\hline
\end{tabular}

Source: European Social Survey (waves 1-8). All values are Beta Coefficients and statistically significant $* * *=(p \leq .001) . * *=p \leq .01 . *=p \leq .05$ Values in brackets are the predictor order.

NB - "n.s." indicates non-significant relationships

NB2 - The analyses use the recommended combination of PSPWGHT and PWEIGHT as per the ESS guidelines (www.europeansocialsurvey.org/docs/methodology/ESS weighting data 1.pdf) 


\section{Notes}

${ }^{1}$ Sander and Putnam (2010) record the doubling of civic engagement amongst college students in the US between 2001 and 2010, but also a growing participation gap between college students and young people who do not go on to university.

${ }^{2}$ The 'EU15' countries are Austria, Belgium, Denmark, Finland, France, Germany, Greece, Ireland, Italy, Luxembourg, the Netherlands, Portugal, Spain, Sweden, and (until it left at $11 \mathrm{pm}$ GMT on 31 January 2020) the UK.

${ }^{3}$ The 'High Education' group includes those holding qualifications that are at least the minimum level necessary to gain admission to university-level study in each country (upper tier upper secondary and above). The Low Education group includes all others who did not achieve this level of educational attainment.

${ }^{4}$ This variable is a composite of the highest qualification achieved variable and the main activity variable, and includes categories of 18 to 24-year-olds who have experience of higher education (HE) and those who do not. The first group includes those who are either currently enrolled in HE or who have previously completed HE studies, while the second group includes young Europeans who have completed their secondary education but did not then continue into HE.

5 'Low-income' refers to the bottom quartile (the bottom three categories on a 12-point scale) of income in each country. 'High-income' refers to the top quartile (on the same scale) of income in each country. Focussing our analyses only on these particular highest and lowest income groups leads to low $\mathrm{N}$ for some sub-samples in the tables and in the analyses.

${ }^{6}$ At the time of examining the data, only waves 1-8 were available for cumulative analysis.

${ }^{7}$ Mean scores rather than percentages are reported for these four "political engagement" variables. Social trust and political trust are both 11 item variables, while there are four categories for political interest and five for political understanding (personal efficacy). See footnote 10 for coding details.

${ }^{8}$ However, numbers are very small, so caution should be exercised when interpreting the figures on party activism, given the rarity of this form of political participation across the EU15.

${ }^{9}$ The nature of the ESS data is not conducive to facilitating direct comparisons across the two regression analyses reported in Tables 3 and 4. The analyses therefore represent the predictive relationships between the variables for each individual group. The comparisons of the relationships between these groups therefore only provide indirect differences between them.

${ }^{10}$ The coding for these variables is as follows: Income $=1$ Low Income, 2 High Income; Educational attainment $=1$ Low Education, 2 High Education; Gender = 1 Male, 2 Female; Ethnicity = 1 Minority ethnic group, 2 Majority ethnic group; Voted [in the] last national election $=1$ Yes, 2 No; Worked in a political party or action group $=1$ Yes, 2 No; Worked in another organisation or association (for a political cause) $=1$ Yes, 2 No; Contacted a politician or government official $=1$ Yes, 2 No; Signed a petition $=1$ Yes, 2 No; Taken part in a lawful public demonstration $=1$ Yes, 2 No; Boycotted certain products $=1$ Yes, 2 No; Trust $($ social $)=0$ Cannot be trusted to 10 Can be trusted; Trust (politicians) $=0$ Cannot be trusted to 10 Can be trusted; Political interest $=1$ Not at all interested to 4 Very interested; 
Political understanding/ Personal efficacy (Politics is too complicated to understand) $=1$ Frequently to 5 Never.

${ }^{11}$ One could make the point that college students - unlike those young people with secondary qualifications who are not in education - are different in that they are clearly on the pathway to higher educational attainment, and thus are more motivated, efficacious individuals. This may well be true but is unlikely to account for such a large gap between young people from poorer backgrounds inside and outside HE (as our analysis demonstrates).

\section{References}

Amnå, E. \& Ekman, J. 2014. Standby Citizens: Diverse Faces of Political Passivity. European Political Science Review 6(2): 261-281.

Arnett, J. 2004. Emerging Adulthood: The Winding Road from Late Teens through the Twenties. Oxford: Oxford University Press.

Bang, H. \& Esmark, A. 2009. Good Governance in the Network Society: Reconfiguring the Political from Politics to Policy. Administrative Theory and Praxis 31(1): 7-37.

Beaumont, E., Colby, A., Ehrlich, T. \& Torney-Purta, J. 2006. Promoting Political Competence and Engagement in College Students: An Empirical Study. Journal of Political Science Education 2(3): 249-270.

Bennett, W. \& Segerberg, A. 2013. The Logic of Connective Action: Digital Media and the Personalization of Contentious Politics. New York: Cambridge University Press.

Berinsky, A. \& Lenz, G. 2011. Education and Political Participation: Exploring the Causal Link. Political Behavior 33(3): 357-373.

Busse, B., Hashem-Wangler, A. \& Tholen, J. 2015. Two Worlds of Participation: Young People and Politics in Germany. The Sociological Review, 63(S2): 118-140.

Cammaerts, B., Bruter, M., Banaji, S., Harrison, S. and Anstead, N., 2016. Youth participation in democratic life: Stories of hope and disillusion. Basingstoke: Palgrave. 
Campbell, D. 2009. Civic Engagement and Education: An Empirical Test of the Sorting Model. American Journal of Political Science 53(4): 771-786.

Castells, M. 2012. Networks of Outrage and Hope: Social Movements in the Internet Age. Cambridge: Polity.

Chadwick, A. 2013. The Hybrid Media System: Politics and Power. Oxford: Oxford University Press.

Colby, A., Ehrlich, T., Beaumont, E. \& Stephens, J. 2003. Educating Citizens: Preparing America's Undergraduates for Lives of Moral and Civic Responsibility. San Francisco: JosseyBass.

Dahl, R. 1971. Polyarchy: Participation and Opposition. New Haven: Yale University Press.

Dalton, R. 2004. Democratic Challenges, Democratic Choices: The Erosion of Political Support in Advanced Industrial Democracies. Oxford: Oxford University Press.

Dalton, R. 2009. The Good Citizen: How a Younger Generation is Reshaping American Politics. Washington, DC: CQ Press.

Della Porta, D. \& Tarrow, S. 2005. Transnational Protest and Global Activism. Oxford: Rowman \& Littlefield.

Dewey, J. 1959. [1916] Democracy and Education: An Introduction to the Philosophy of Education. New York: Macmillan.

European Commission. 2007. Young Europeans: Survey Among Young People Aged Between 15-30 in the European Union (Eurobarometer 202), European Commission: http://ec.europa.eu/public_opinion/flash/fl_202_sum_en.pdf (accessed 7 September 2020).

European Commission. 2009. Youth in Europe: A statistical portrait of the lifestyle of young people, European Commission: https://ec.europa.eu/commission/presscorner/detail/en/STAT_09_177 (accessed 7 September 2020). 
European Commission. 2019. Population with Tertiary Education. European Commission: https://ec.europa.eu/eurostat/statistics-explained/index.php/Tertiary_education_statistics (accessed 7 September 2020).

Fieldhouse E., Tranmer, M. \& Russell, A. 2007. Something About Young People or Something About Elections? Electoral Participation of Young People in Europe: Evidence From a Multilevel Analysis of the European Social Survey. European Journal of Political Research 46(6): 797-822.

Flanagan, C. 2013. Teenage Citizens: The Political Theories of the Young. Cambridge, MA: Harvard University Press.

Flanagan, C., Cumsille, P., Gill, S. \& Gallay, L. 2007. School and Community Climates and Civic Commitments: Processes for Ethnic Minority and Majority Students. Journal of Educational Psychology 99(2): 421-431.

Flanagan, C., Finlay, A., Gallay, L. \& Kim, T. 2012. Political Incorporation and the Protracted Transition to Adulthood: The Need for New Institutional Inventions. Parliamentary Affairs 65(1): 29-46.

Flanagan, C. \& Levine, P. 2010. Civic Engagement and the Transition to Adulthood. The Future of Children 20(1): 159-179.

Franklin, M. 2004. Voter Turnout and the Dynamics of Electoral Competition since 1945. Cambridge: Cambridge University Press.

Furlong, A. \& Cartmel, F. 2012. Social Change and Political Engagement Among YoungPeople: Generation and the 2009/2010 British Election Survey. Parliamentary Affairs 65(1): 13-28.

Galston, W. 2001. Political Knowledge, Political Engagement, and Civic Education. Annual Review of Political Science, 4: 217-234.

Gelmon, S.B., Holland, B.A. \& Spring, A. 2018. Assessing service-learning and civic engagement: Principles and techniques. Boston: Stylus. 
Giddens, A. 1991. Modernity and Self-Identity: Self and Society in the Late Modern Age. Cambridge: Polity.

Goddard, J., Hazelkorn, E. \& Vallance, P. (eds.). 2016. The civic university: The policy and leadership challenges. Cheltenham: Edward Elgar.

Grasso, M.T. 2016. Generations, political participation and social change in Western Europe. London: Routledge.

Grasso, M.T., Yoxon, B., Karampampas, S. and Temple, L., 2017. Relative deprivation and inequalities in social and political activism. Acta Politica, pp.1-32.

Hay, C. 2007. Why We Hate Politics. Cambridge: Polity.

Heath, A., Fisher, S., Sanders, D. \& Sobolewska, M. 2011. Ethnic Heterogeneity in the Social Bases of Voting at the 2010 British General Election. Journal of Elections, Public Opinion and Parties 21(2): 255-277.

Henn, M. \& Foard, N. 2014. Social Differentiation in Young People's Political Participation: The Impact of Social and Educational Factors on Youth Political Engagement in Britain. Journal of Youth Studies 17(3): 360-380.

Henn, M., Oldfield, B. \& Hart, J. 2018. Postmaterialism and Young People's Political Participation in a Time of Austerity. British Journal of Sociology 69(3): 712-737.

House of Commons Political and Constitutional Reform Committee. 2014. Voter Engagement in the UK, Fourth Report of Session 2014-15. London: The Stationery Office Limited.

Jacoby, B. \& associates. 2009. Civic Engagement in Higher Education: Concepts and Practices. San Francisco: Jossey-Bass.

Jennings, M. \& Stoker, L. 2004. Social Trust and Civic Engagement across Time and Generations. Acta Politica 39(4): 342-379.

Kam, C. \& Palmer, C. 2008. Reconsidering the Effects of Education on Political Participation. The Journal of Politics 70(3): 612-631. 
Keating, A. 2014. Education for Citizenship in Europe: European Policies, National Adaptations, and Young People's Attitudes. Basingstoke: Palgrave.

Keating, A., Kerr, D., Benton, T., Mundy, E. \& Lopes, J. 2010. Citizenship Education in England 2001-2010: Young People's Practices and Prospects for the Future: The Eighth and Final Report from the Citizenship Education Longitudinal Study. London: DfE.

Kerr, D., Lopes, J., Nelson, J., White, K., Cleaver, E. \& Benton, T. 2007. Vision versus Pragmatism: Citizenship in the Secondary School Curriculum in England. Citizenship Education Longitudinal Study: Fifth Annual Report. Slough: NFER.

Kyroglou, G. and Henn, M. 2017. Political Consumerism as a Neoliberal Response to Contemporary Youth Political Disengagement. Societies 7(4): 34.

Levinson, M. 2010. The Civic Empowerment Gap: Defining the Problem and Locating Solutions. In L. Sherrod, J. Torney-Purta \& C. Flanagan (eds), Handbook of Research on Civic Engagement in Youth. Hoboken, NJ: John Wiley \& Sons.

Lewis-Beck, M., Jacoby, W., Norpoth, H. \& Weisberg, H. 2008. The American Voter Revisited. Ann Arbor: The University of Michigan Press.

Longo, N., Drury, C. \& Battistoni, R. 2006. Catalyzing Political Engagement: Lessons for Civic Educators from the Voices of Students. Journal of Political Science Education 2(3): 313-329.

Marien, S., Hooghe, M. \& Quintelier, E. 2010. Inequalities in Non-institutionalised Forms of Political Participation: A Multi-level Analysis of 25 Countries. Political Studies 58(1): 187213.

Mossberger, K., Tolbert, C. \& McNeal, R. 2007. Digital Citizenship: The Internet, Society and Participation. Cambridge, MA: MIT Press.

Nie, N., Junn, J. \& K. Stehlik-Barry, K. 1996. Education and Democratic Citizenship in America. Chicago: University of Chicago Press. 
Niemi, R., \& Junn, J. 1998. Civic Education: What Makes Students Learn. New Haven: Yale University Press.

Nissen, S. 2019. Student debt and political participation. Basingstoke: Palgrave.

Norris, P. 2011. Democratic Deficit: Critical Citizens Revisited. New York: Cambridge University Press.

Norris, P. \& Inglehart, R. 2009. Cosmopolitan Communications: Cultural Diversity in a Globalised World. Cambridge: Cambridge University Press.

Norris, P. \& Inglehart, R. 2019. Cultural Backlash: Trump, Brexit, and Authoritarian Populism. New York: Cambridge University Press.

Norris, P., Walgrave, S. \& Van Aelst, P. 2005. Who Demonstrates? Antistate Rebels, Conventional Participants, or Everyone? Comparative Politics 37(2): 189-205.

Parry, G., Moyser, G. \& Day, N. 1992. Political Participation and Democracy in Britain. Cambridge: Cambridge University Press.

Pasek, J., Feldman, L., Romer, D. \& Jamieson, K. 2008. Schools as Incubators of Democratic Participation: Building Long-term Political Efficacy with Civic Education. Applied Development Science 12(1): 26-37.

Pattie, C., Seyd, P. \& Whiteley, P. 2004. Citizenship in Britain: Values, Participation and Democracy. Cambridge: Cambridge University Press.

Pickard, S. 2019. Young people and DIO politics: do-it-ourselves political participation. London: Palgrave.

Pickard, S. \& Bessant, J. (eds.) 2018. Young people re-generating politics in times of crises. Basingstoke: Palgrave Macmillan.

Pryor, J., Hurtado, S., DeAngelo, L., Sharkness, J., Romero, L., Korn, W. \& Tran, S. 2008. The American Freshman: National Norms Fall 2008. Los Angeles: Higher Education Research Institute. 
https://www.heri.ucla.edu/PDFs/pubs/TFS/Norms/Monographs/TheAmericanFreshman2008. pdf (accessed 23 September 2020).

Putnam, R. 2000. Bowling Alone: The Collapse and Revival of American Community. New York: Simon \& Schuster.

Sander, T. \& Putnam, R. 2010. Still Bowling Alone? The Post-9/11 Split. Journal of Democracy 21(1): 9-16.

Schlozman, K., Verba, S. \& Brady, H. 2010. Weapon of the Strong? Participatory Inequality and the Internet. Perspectives on Politics 8(2): 487-509.

Schulz, W., Ainley, J., Fraillon, J., Kerr, D. \& Losito, B. 2010. ICCS 2009 International Report: Civic Knowledge, Attitudes and Engagement Among Lower Secondary School Students in Thirty-eight Countries. Amsterdam: International Association for the Evaluation of Educational Achievement.

Sloam, J. 2013. 'Voice and equality': Young People's Politics in the European Union. West European Politics 36(4): 836-858.

Sloam, J. 2016. Diversity and voice: The political participation of young people in the European Union. The British Journal of Politics and International Relations, 18(3): 521-537.

Sloam, J., \& Henn, M. 2019. Youthquake 2017: The Rise of Young Cosmopolitans in Britain. Basingstoke: Palgrave.

Soler-i-Martí, R. 2015. Youth Political Involvement Update: Measuring the Role of Causeorientated Political Interest in Young People's Activism. Journal of Youth Studies 18(3): 396416.

Steiner, D. 1994. Rethinking Democratic Education: The Politics of Reform. Baltimore, MD: Johns Hopkins University Press.

Stoker, G. 2006. Why Politics Matters: Making Democracy Work. Basingstoke: Palgrave. 
Stolle, D. \& Hooghe, M. 2011. Shifting Inequalities: Patterns of Exclusion and Inclusion in Emerging Forms of Political Participation. European Societies 13(1): 119-142.

Stolle, D., Hooghe, M. \& Micheletti, M. 2005. Politics in the Supermarket: Political Consumerism as a Form of Political Participation. International Political Science Review 26(3): 245-269.

Tormey, S. 2015. The End of Representative Politics. Cambridge: Polity Press.

Torney-Purta, J., Lehmann, R., Oswald, H. \& Schulz, W. 2001. Citizenship and Education in Twenty-eight Countries: Civic Knowledge and Engagement at Age Fourteen. Amsterdam: IEA.

Van Deth, J., Ramón Montero, J. \& Westholm, A. 2007. Citizenship and Involvement in European Democracies: A Comparative Analysis. London: Routledge.

Verba, S. \& Nie, N. 1972. Participation in America: Political Democracy and Social Equality. New York: Harper \& Row.

Verba S., Schlozman, K. \& H. Brady, H. 1995. Voice and Equality: Civic Voluntarism in American Politics. Cambridge, MA: Harvard University Press.

Wolfinger, R. \& Rosenstone, S. 1980. Who Votes? New Haven: Yale University Press.

Youth Citizenship Commission. 2009. Making the Connection: Building Youth Citizenship in the $U K$. London: Stationery Office. 